\title{
Tillage, Crop Residue and Nitrogen Management Effects on Nitrogen Uptake, Nitrogen Use Efficiency and Yield of Rice
}

\author{
Arjun Bastola $^{1, a, *}$, Tika Karki ${ }^{2, b}$, Santosh Marahatta ${ }^{1, c}$, Lal Prasad Amgain ${ }^{3, d}$ \\ ${ }^{1}$ Agriculture and Forestry University, Rampur, Chitwan, Nepal \\ ${ }^{2}$ Nepal Agricultural Research Council, Kathmandu, Nepal \\ ${ }^{3}$ Faculty of Agriculture, Far-Western University, Tikapur, Nepal \\ ${ }^{*}$ Corresponding author
}

\section{A R T I C LE I N F O}

Research Article

Received : 08/11/2019

Accepted : 20/12/2019

\section{Keywords:}

Tillage

Residue

Nitrogen uptake

Nitrogen use efficiency

Rice yield

\begin{abstract}
A B S T R A C T
Field experiment was conducted in three factorial strip split plot design to evaluate the effect of two establishment methods (EM) i.e. transplanted in puddled soil (Pu-TPR) and direct seeded in zero tillage (ZT-DSR), two residue levels i.e. residue kept at $3 \mathrm{t} \mathrm{ha}^{-1}(\mathrm{RK})$ and no residue (RR) with two nitrogen doses i.e. recommended dose $\left(100 \mathrm{~kg} \mathrm{~N} \mathrm{ha}^{-1}\right)(\mathrm{RD})$ and farmers' dose $\left(50 \mathrm{~kg} \mathrm{~N} \mathrm{ha}^{-1}\right)$ (FD) with six replications with individual plot size of $5.4 \mathrm{~m} \times 6.3 \mathrm{~m}$ on rice variety Ramdhan during the year 2016. Nitrogen uptake, nitrogen use efficiencies and yield of rice were recorded. Straw nitrogen uptake was significantly higher in ZT-DSR than Pu-TPR. Similarly, grain straw and total nitrogen uptake were significantly higher in residue applied and recommended dose of nitrogen than noresidue applied and farmers-nitrogen dose treatments respectively. Nitrogen efficiency ratio and physiological efficiency index were significantly higher in Pu-TPR and no-residue applied treatments while partial factor productivity was higher in residue applied treatment. All nitrogen use efficiencies like partial factor productivity, nitrogen efficiency ratio and physiological efficiency index were significantly influenced by nitrogen dose and seen higher in recommended dose of nitrogen. Establishment methods had no significant effect on grain yield but straw yield was significantly higher in ZT-DSR but harvest index was seen higher in Pu-TPR. Grain yield and straw yield were significantly higher in residue applied treatment and recommended nitrogen but harvest index was higher in farmers-nitrogen dose.
\end{abstract}

arjunbastola143@gmail.com (i) https://orcid.org/0000-0001-8216-6204

santoshmarahatta@gmail.com

(iD) https://orcid.org/0000-0001-8216-6204

b@tbkarki2003@gmail.com
$\mathbf{d}$ amgainlp@gmail.com

(iD https://orcid.org/0000-0003-1653-7139

(iD) https://orcid.org/0000-0001-9397-0927

(c) (1) (8) This work is licensed under Creative Commons Attribution 4.0 International License

\section{Introduction}

Rice (Oryza sativa L.) is the world's third crop on the basis of volume of production (503.2 million tons) after wheat and maize (FAO, 2017). It is the staple food of more than $60 \%$ of the world's population and about $95 \%$ of global rice is grown and consumed in Asian region (Alam et al., 2009). In Nepal, it can be cultivated under all agro-climatic zones and covers 1.55 million ha with total production of 5.23 million tons and productivity of $3.37 \mathrm{t} \mathrm{ha}^{-1}$ (MoAD, 2016). Rice is the most important staple food crop, extensively cultivated in Nepal. It only accounts for more than $50 \%$ of the total calories of Nepalese people (Gadal et al., 2019; Devkota et al., 2019). It is grown in three agroecological regions (terai and inner terai, mid hills and high hills) under irrigated, rain-fed lowland and upland production environment. Terai is the main rice cultivation area produced 70 percent of the total rice, while the hills and mountain contribute 26 percent and 4 percent respectively (Adhikari et al., 2018). Rice is generally cultivated by two methods: transplanting in puddled soil and direct seeding (DSR). Puddling adversely affects soil physical properties by dismantling soil aggregates, reducing permeability in subsurface layers (Sharma et al., 2003). Therefore, it is suggested that alternate method of planting i.e. Dry-DSR is gaining popularity regarding its high-water use, labor use and energy use efficiencies (Kumar and Ladha, 2011). Crop residue is useful for conserving and sustaining soil productivity. Sehgal and Abrol (1994) have reported no addition of crop residue as one of the major reason of degradation of marginal lands. Wheat stalk, maize stover and rice straw are usually removed from fields for use as cattle feed and for purposes such as livestock bedding, thatching material for houses or for fuel, leaving little for incorporation into the soil (Singh, 2003).

Nitrogen is one of the most important essential nutrients for growth of plant as it is important component of RNA, DNA, amino acids, nucleic acids, nucleotides, chlorophyll, enzymes, and hormones. A large portion of applied nitrogen losses from flooded rice field which contribute to the low $\mathrm{N}$ use efficiency of rice as compared to another crop (Karkee et al., 2019). The lack of 
availability of nitrogenous fertilizers at the time of need and lack of capital in the resource poor farmers cause the lower dose of nitrogen application than recommended nitrogen dose. Mahajan and Timsina (2011) observed that DSR required more nitrogen than transplanted rice. In comparison with transplanted rice, nitrogen loss through denitrification, volatilization, leaching and runoff is higher in conservation agriculture (Kumar and Ladha, 2011). The objective of this research was to assess the effects of establishment methods, residue and nitrogen on the nitrogen uptake, nitrogen use efficiency and yield of rice.

\section{Materials and Methods}

A field experiment was carried out at agronomy farm of National Maize Research Program, Chitwan, Nepal from June to November, 2016 in sandy loam textured soil with slightly acidic $\mathrm{pH}$. The geographical location of the experiment site was located at $27^{\circ} 40^{\prime} \mathrm{N}$ latitude, $84^{\circ} 19^{\prime} \mathrm{E}$ and 228 meters above sea level and has sub-tropical climate (Gurung et al., 2018). Three factorial strip-split plot design was used with establishment method as horizontal factor, residue as vertical factor and nitrogen levels as sub plot factor with two levels each which were replicated six times. Establishment methods involved (i) zero till direct seeded rice (ZT-DSR) (ii) puddled transplanting rice (PTR). Vertical factor involved (i) residue kept and (ii) residue removed and sub plot factor includes two nitrogen levels (i) recommended dose as $100 \mathrm{~kg} \mathrm{~N} \mathrm{ha}^{-1}$ (RD) and (ii) farmers' field practice dose as $50 \mathrm{~kg} \mathrm{~N} \mathrm{ha}^{-1}$ (FD). The total rainfall during research was $1646.20 \mathrm{~mm}$. Average relative humidity and average maximum and minimum temperature was $84.58 \%, 22.98^{\circ} \mathrm{C}$ and $32.32^{\circ} \mathrm{C}$ respectively. The soil of experiment locations had organic matter (0.09-2.04\%), available phosphorus (19.73-32.3 $\mathrm{kg} \mathrm{ha}^{-1}$ ) and available potassium (67-134 $\left.\mathrm{kg} \mathrm{ha}^{-1}\right)$. The variety used in the trial was Ramdhan. Seed were sown at rate of $50 \mathrm{~kg} \mathrm{ha}^{-1}$ on $22^{\text {nd }}$ of
June 2016 for ZT-DSR at the spacing of $20 \mathrm{~cm}$ between the lines and for puddled TPR nursery bed preparation was done on same day and 30 days old seedlings were transplanted. Pendimethalin was sprayed on the next day after sowing at the rate of $1 \mathrm{~kg}$ active ingredients $\mathrm{ha}^{-1} . \mathrm{P}$ and $\mathrm{K}$ at the rate of 30: $30 \mathrm{~kg} \mathrm{ha}^{-1}$ and $1 / 3^{\text {rd }} \mathrm{N}$ was applied at basal dose and remaining $1 / 3^{\text {rd }} \mathrm{N}$ at active tillering stage and remaining $\mathrm{N}$ $1 / 3^{\text {rd }}$ at panicle initiation stage. Two hand weeding was done at 20 days after sowing (DAS) and 40 DAS. The irrigation was done to the entire plot at the time of needed on continuous basis. Irrigation was withheld 10 days before crop harvest. All other practices during crop growth period were as per the package of practices for the crops. The crop was harvested and threshed manually and yield was computed at $14 \%$ moisture content. Data on grain and straw nitrogen uptake, partial factor productivity, nitrogen efficiency ratio, physiological efficiency index, grain yield, straw yield and harvest index were recorded at the time of crop harvest. The experimental data were processed by using Excel 2010 and analyzed by using Genstat 13.2. The treatment means were compared by the Least Significant Difference (LSD) test at 5\% level (Gomez and Gomez, 1984; Shrestha, 2019).

\section{Results and Discussion}

\section{Nitrogen Uptake and Nitrogen Use Efficiency}

In establishment methods, only straw nitrogen uptake was significantly higher in ZT-DSR but grain and total nitrogen uptake was non-significant but uptake by grain was higher in puddled TPR and total was higher in ZTDSR. Residue and nitrogen dose significantly affect grain, straw and total nitrogen uptake and all uptakes were higher in residue application and in recommended nitrogen dose respectively (Table 1). Oo et al. (2007) also found significantly higher uptake of nitrogen by grain, straw and also total $\mathrm{N}$ uptake in $100 \mathrm{~kg} \mathrm{~N} \mathrm{ha}^{-1}$ than in $50 \mathrm{~kg} \mathrm{~N} \mathrm{ha}^{-1}$.

Table 1. Grain, straw and total nitrogen uptake by rice as influenced by establishment methods, residue and nitrogen dose in Chitwan during 2016

\begin{tabular}{|c|c|c|c|}
\hline Treatment & Grain nitrogen uptake $\left(\mathrm{kg} \mathrm{ha}^{-1}\right)$ & Straw nitrogen uptake $\left(\mathrm{kg} \mathrm{ha}^{-1}\right)$ & Total nitrogen uptake $\left(\mathrm{kg} \mathrm{ha}^{-1}\right)$ \\
\hline \multicolumn{4}{|c|}{ Establishment methods } \\
\hline ZT-DSR & 54.95 & $53.42^{\mathrm{a}}$ & 108.37 \\
\hline Pu-TPR & 57.78 & $43.37^{\mathrm{b}}$ & 101.15 \\
\hline $\operatorname{SEm}( \pm)$ & 1.93 & 1.30 & 2.89 \\
\hline $\operatorname{LSD}(0.05)$ & ns & 4.73 & ns \\
\hline $\mathrm{CV}(\%)$ & 8.40 & 6.60 & 6.80 \\
\hline \multicolumn{4}{|c|}{ Residues } \\
\hline With Residue & $58.94^{\mathrm{a}}$ & $54.86^{\mathrm{a}}$ & $113.80^{\mathrm{a}}$ \\
\hline Without Residue & $53.79^{\mathrm{b}}$ & $41.93^{\mathrm{b}}$ & $95.72^{\mathrm{b}}$ \\
\hline $\operatorname{SEm}( \pm)$ & 0.76 & 1.48 & 2.05 \\
\hline $\operatorname{LSD}(0.05)$ & 2.77 & 5.39 & 7.47 \\
\hline $\mathrm{CV}(\%)$ & 3.30 & 7.50 & 4.80 \\
\hline \multicolumn{4}{|c|}{ Nitrogen Dose } \\
\hline $\mathrm{RD}$ & $66.85^{\mathrm{a}}$ & $60.95^{\mathrm{a}}$ & $127.80^{\mathrm{a}}$ \\
\hline FD & $45.88^{\mathrm{b}}$ & $35.84^{\mathrm{b}}$ & $81.72^{\mathrm{b}}$ \\
\hline $\operatorname{SEm}( \pm)$ & 1.16 & 0.83 & 1.68 \\
\hline $\operatorname{LSD}(0.05)$ & 3.43 & 2.43 & 4.97 \\
\hline $\mathrm{CV}(\%)$ & 10.10 & 8.30 & 7.90 \\
\hline Grand Mean & 56.36 & 48.40 & 104.76 \\
\hline
\end{tabular}

Note: ZT-DSR, Zero tilled direct seeded rice; Pu-TPR, Puddled transplanted rice; RD, Recommended dose; FD, Farmers practice dose; ns, nonsignificance. Treatments means followed by different letter (s) are significantly different among each other based on DMRT at $5 \%$ level of significance 
Table 2. Nitrogen use efficiencies of rice as influenced by establishment methods, residue and nitrogen dose in Chitwan during 2016

\begin{tabular}{|c|c|c|c|}
\hline Treatment & $\begin{array}{l}\text { Partial factor productivity } \\
\quad(\mathrm{kg} \text { grain } / \mathrm{kg} \mathrm{N})\end{array}$ & $\begin{array}{c}\text { Nitrogen efficiency } \\
\text { ratio (kg biomass/kg N uptake) }\end{array}$ & $\begin{array}{c}\text { Physiological efficiency } \\
\text { index (kg grain / kg N uptake) }\end{array}$ \\
\hline \multicolumn{4}{|c|}{ Establishment methods } \\
\hline ZT-DSR & 53.88 & $84.38^{\mathrm{b}}$ & $35.42^{\mathrm{b}}$ \\
\hline Pu-TPR & 58.96 & $87.52^{\mathrm{a}}$ & $41.78^{\mathrm{a}}$ \\
\hline $\operatorname{SEm}( \pm)$ & 1.77 & 0.18 & 0.38 \\
\hline $\operatorname{LSD}(0.05)$ & ns & 0.66 & 1.39 \\
\hline $\mathrm{CV}(\%)$ & 7.70 & 0.50 & 2.40 \\
\hline \multicolumn{4}{|c|}{ Residues } \\
\hline With Residue & $60.25^{\mathrm{a}}$ & $84.44^{\mathrm{b}}$ & $37.80^{\mathrm{b}}$ \\
\hline Without Residue & $52.59^{\mathrm{b}}$ & $87.47^{\mathrm{a}}$ & $39.40^{\mathrm{a}}$ \\
\hline $\operatorname{SEm}( \pm)$ & 1.21 & 0.16 & 0.33 \\
\hline LSD (0.05) & 4.40 & 0.59 & 1.22 \\
\hline $\mathrm{CV}(\%)$ & 5.30 & 0.50 & 2.10 \\
\hline \multicolumn{4}{|c|}{ Nitrogen Dose } \\
\hline $\mathrm{RD}$ & $45.56^{\mathrm{b}}$ & $83.67^{\mathrm{b}}$ & $35.94^{\mathrm{b}}$ \\
\hline FD & $67.28^{\mathrm{a}}$ & $88.23^{\mathrm{a}}$ & $41.26^{\mathrm{a}}$ \\
\hline $\operatorname{SEm}( \pm)$ & 1.30 & 0.13 & 0.28 \\
\hline LSD (0.05) & 3.83 & 0.38 & 0.81 \\
\hline $\mathrm{CV}(\%)$ & 11.30 & 0.70 & 3.50 \\
\hline Grand Mean & 56.42 & 85.95 & 38.60 \\
\hline
\end{tabular}

Note: ZT-DSR, Zero tilled direct seeded rice; Pu-TPR, Puddled transplanted rice; RD, Recommended dose; FD, Farmers practice dose; ns, nonsignificance. Treatments means followed by different letter (s) are significantly different among each other based on DMRT at 5\% level of significance

Partial factor productivity, nitrogen efficiency ratio and physiological efficiency index was seen higher in Puddled TPR as compared to ZT-DSR and also higher in residue removed plot over residue kept plot except partial factor productivity and all the efficiencies were seen significantly higher in lower nitrogen dose as compared to recommended nitrogen dose (Table 2). Kumar and Ladha (2011) mentioned that nutrient use efficiencies are lower in DSR compared to puddled TPR. The organic matter which have high $\mathrm{C}$ : $\mathrm{N}$ ratio is subjected to ammonification in anaerobic condition which enhance the higher ammonium release despite of higher decomposition in the aerobic condition (Patrick and Wyatt, 1964). Reddy et al. (1984) described that ammonium $\mathrm{N}$ accumulated in anaerobic condition i.e. in puddled field condition contributed to $60 \%$ of rice nitrogen need and higher uptake under this condition. The other reason of lower ammonium $\mathrm{N}$ might be due to nitrification of ammonium and subsequent denitrification under anaerobic condition (Zia et al., 2001) leading to lower uptake under DSR and lower use efficiencies of applied nitrogen compared with puddled TPR. Haque et al. (2016) observed that nitrogen use efficiency was significantly higher in plots applied $60 \mathrm{~kg}$ $\mathrm{N} \mathrm{ha}^{-1}$ and lower in $100 \mathrm{~kg} \mathrm{~N} \mathrm{ha}^{-1}$.

Partial factor productivity was significantly influenced by the interaction between residue and nitrogen dose (Figure 1A). In farmers-nitrogen dose residue application had significantly higher partial factor productivity than no residue application but in recommended dose both residue application practices had statistically similar partial factor productivity. Establishment methods and residue also had significant interaction on nitrogen efficiency ratio (Figure 1B). In ZT-DSR without residue application had significantly higher nitrogen efficiency ratio than residue application treatment but in puddled TPR both residue application treatment had statistically similar nitrogen efficiency ratio.
Three way interactions of establishment methods, residue management and nitrogen dose was recorded for nitrogen efficiency ratio (Table 3 ). In no residue application treatment both establishment methods had statistically at par nitrogen efficiency ratio in both the nitrogen dose but in residue application treatment puddled TPR had significantly higher nitrogen efficiency ratio than ZT-DSR in both nitrogen dose.

Establishment methods and residue had significant interaction on physiological efficiency index (Figure 2A). In ZT-DSR no residue application had significantly higher physiological efficiency index than residue application treatment but in puddled TPR both reside application had at par physiological efficiency index. There was also significant interaction of residue and nitrogen dose on physiological efficiency index (Figure 2B). In recommended nitrogen dose residue applied plot had significantly lower physiological efficiency index than no residue application plot but in farmers-nitrogen dose both residue treatment had statistically similar physiological efficiency index.

\section{Grain Yield, Straw Yield and Harvest Index}

In our experiment establishment methods had no significant effect on grain yield of rice (Table 4). Sah et al. (2014) also had the similar findings where they observed non-significant effect on grain yield by establishment methods in year 2010/11. The results are in contrasting with the result found by Ehsanullah et al. (2000). Sah et al. (2014) in their trial during 2011/12 observed significantly higher grain yield in transplanting methods. Grain yield was found significantly higher in residue kept plot than residue removed plot in our experiment. Sah et al. (2014) in year 2011/12 observed significantly higher grain yield in residue retention treatment than residue removable. Hobbs et al. (2002) observed higher grain yield in residue kept treatment than residue removed treatment. 
Recommended dose of nitrogen significantly produced higher grain yield of rice than farmers' dose. Sah et al. (2014), observed significantly higher grain yield with abundant nitrogen dose than farmers-nitrogen dose. Sharma and Ghosh (2000) also obtained that with successive increase in nitrogen dose up to $120 \mathrm{~kg} \mathrm{~N}^{-1}$ grain yield also increased significantly. Residue incorporation also significantly influenced the straw yield and found higher yield in residue kept than residue removed. As stated earlier residue benefits by soil moisture conservation, minimizing weed growth and organic matter addition in the soil which makes good crop growth and biomass. Sharma and Mitra (1992) also observed that wheat straw applied at the rate of $5-10 \mathrm{tha}^{-1}$ alone gave higher grain yield of rice than the plots with no residue applied. Arshadullah et al. (2012) also found the similar findings. Nitrogen dose also significantly affect the straw yield and higher yield was obtained in recommended nitrogen dose. Oo et al. (2007) also observed significantly higher straw yield in $100 \mathrm{~kg} \mathrm{~N} \mathrm{ha}^{-1}$ over $50 \mathrm{~kg} \mathrm{~N} \mathrm{ha}^{-1}$ and control plots but $100 \mathrm{~kg} \mathrm{~N}^{-1}$ and $150 \mathrm{~kg} \mathrm{~N}^{-1}$ had statistically similar straw yield. Togari et al. (1954) and Fageria (2014) stated that higher nitrogen helps in the metabolism of protein and ultimately the metabolism of carbohydrate in the latter stages of growth which might be the cause for significantly higher production of total above ground biomass and ultimately higher production of straw. Harvest index was also significantly influenced by the establishment methods and found higher harvest index in puddled-TPR than ZT-DSR. Ehsanullah et al. (2000) also reported significantly higher harvest index in transplanted rice than others direct seeding methods of rice cultivation.

Table 3. Nitrogen efficiency ratio as influenced by interaction between establishment methods, residue and nitrogen dose in Chitwan during 2016

\begin{tabular}{|c|c|c|c|c|}
\hline \multirow{2}{*}{ Establishment methods } & \multicolumn{2}{|c|}{ With Residue } & \multicolumn{2}{|c|}{ Without Residue } \\
\hline & Recommended dose & Farmers' dose & Recommended dose & Farmers' dose \\
\hline ZT-DSR & $79.10^{\mathrm{e}}$ & $84.09^{\mathrm{d}}$ & $85.63^{\mathrm{c}}$ & $88.72^{\mathrm{b}}$ \\
\hline Pu-TPR & $83.85^{\mathrm{d}}$ & $90.71^{\mathrm{a}}$ & $86.13^{c}$ & $89.41^{\mathrm{b}}$ \\
\hline $\begin{array}{l}\operatorname{Sem}( \pm) \\
\operatorname{LSD}(0.05)\end{array}$ & & & & \\
\hline
\end{tabular}

Note: ZT-DSR, Zero tilled direct seeded rice; Pu-TPR, Puddled transplanted rice; RD, Recommended dose; FD, Farmers practice dose; ns, nonsignificance. Treatments means followed by different letter (s) are significantly different among each other based on DMRT at 5\% level of significance
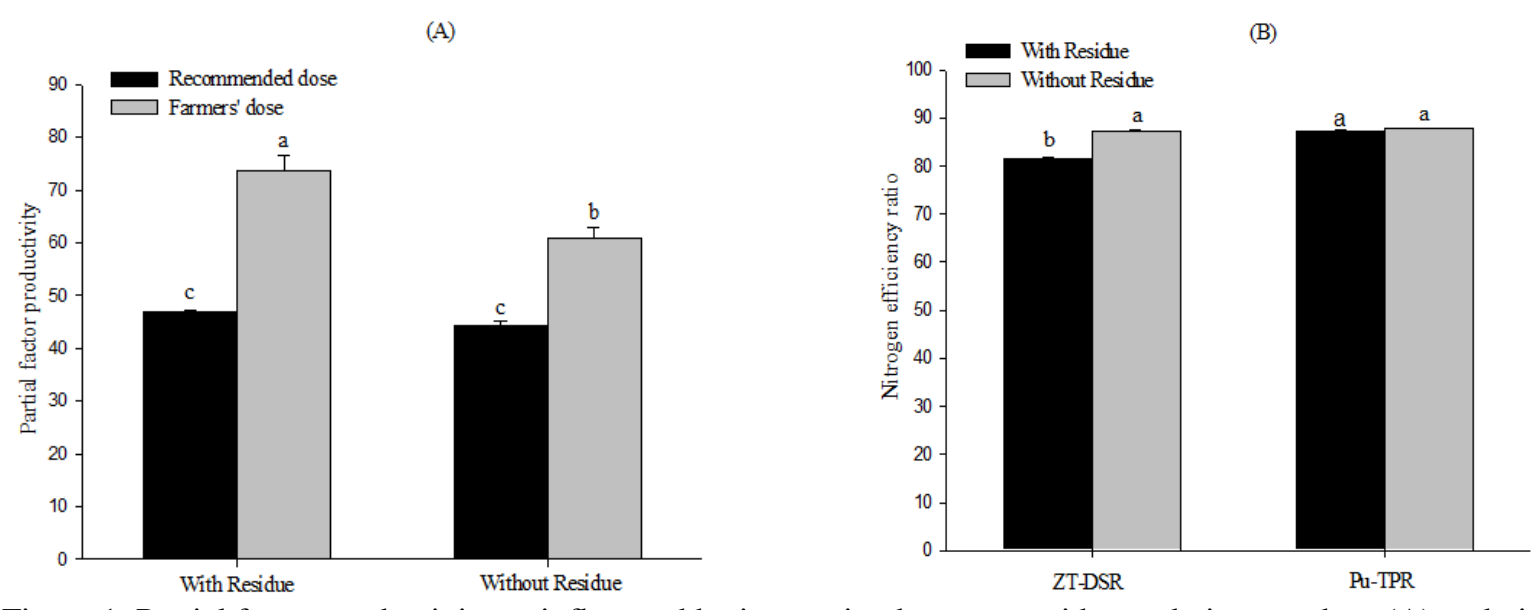

Figure 1. Partial factor productivity as influenced by interaction between residue and nitrogen dose (A) and nitrogen efficiency ratio as influenced by interaction establishment methods and residue (B) in Chitwan during 2016

(A)

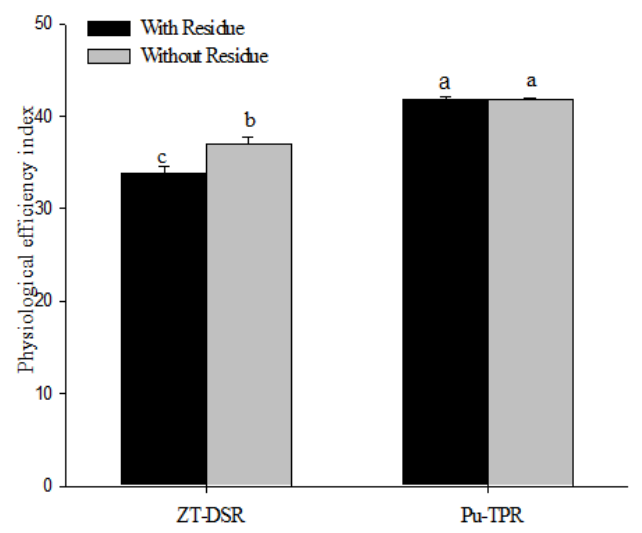

(B)

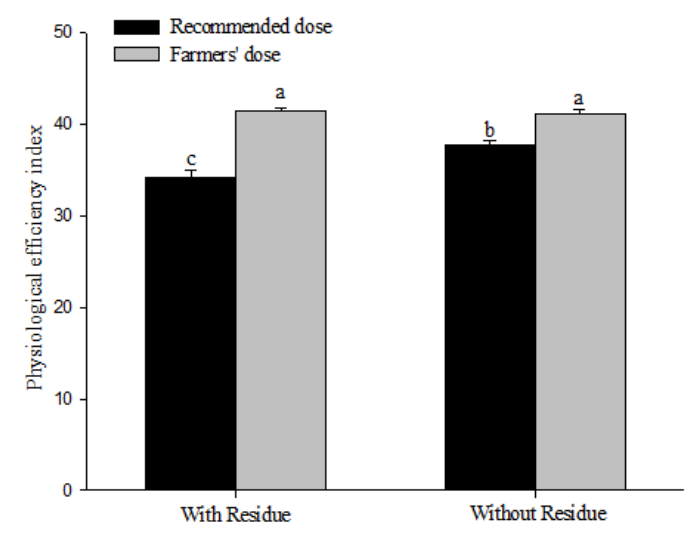

Figure 2. Physiological efficiency index as influenced by the interaction between establishment methods and residue (A) and residue and nitrogen dose (B) in Chitwan during 2016 
Table 4. Grain yield, straw yield, and harvest index of rice as influenced by establishment methods, residue and nitrogen dose in Chitwan during 2016

\begin{tabular}{|c|c|c|c|}
\hline Treatments & Grain Yield $\left(\mathrm{t} \mathrm{ha}^{-1}\right)$ & Straw Yield (t ha $\left.{ }^{-1}\right)$ & Harvest Index (\%) \\
\hline \multicolumn{4}{|c|}{ Establishment methods } \\
\hline ZT-DSR & 4.30 & $5.31^{\mathrm{a}}$ & $41.88^{\mathrm{b}}$ \\
\hline Pu-TPR & 4.80 & $4.62^{b}$ & $47.70^{\mathrm{a}}$ \\
\hline $\operatorname{SEm}( \pm)$ & 0.2 & 0.1 & 0.7 \\
\hline LSD (0.05) & ns & 0.5 & 2.6 \\
\hline $\mathrm{CV}(\%)$ & 8.4 & 6.3 & 3.9 \\
\hline \multicolumn{4}{|c|}{ Residues } \\
\hline With Residue & $4.81^{\mathrm{a}}$ & $5.34^{\mathrm{a}}$ & 44.6 \\
\hline Without Residue & $4.27^{b}$ & $4.60^{\mathrm{b}}$ & 45.0 \\
\hline $\operatorname{SEm}( \pm)$ & 0.1 & 0.1 & 0.6 \\
\hline $\operatorname{LSD}(0.05)$ & 0.2 & 0.5 & ns \\
\hline $\mathrm{CV}(\%)$ & 3.5 & 7.1 & 3.1 \\
\hline \multicolumn{4}{|c|}{ Nitrogen Dose } \\
\hline $\mathrm{RD}$ & $5.24^{\mathrm{a}}$ & $6.11^{\mathrm{a}}$ & $42.88^{b}$ \\
\hline FD & $3.85^{\mathrm{b}}$ & $3.83^{\mathrm{b}}$ & $46.70^{\mathrm{a}}$ \\
\hline $\operatorname{SEm}( \pm)$ & 0.1 & 0.1 & 0.4 \\
\hline $\operatorname{LSD}(0.05)$ & 0.2 & 0.2 & 1.2 \\
\hline $\mathrm{CV}(\%)$ & 7.3 & 7.8 & 4.1 \\
\hline Grand Mean & 4.5 & 5.0 & 44.8 \\
\hline
\end{tabular}

Note: ZT-DSR, Zero tilled direct seeded rice; Pu-TPR, Puddled transplanted rice; RD, Recommended dose; FD, Farmers practice dose; ns, nonsignificance. Treatments means followed by different letter (s) are significantly different among each other based on DMRT at 5\% level of significance

Table 5. Harvest index of rice as influenced by establishment methods, residue and nitrogen dose in Chitwan during 2016

\begin{tabular}{l|cccc}
\hline \multirow{2}{*}{ Establishment methods } & \multicolumn{2}{|c}{ With Residue } & \multicolumn{2}{c}{ Without Residue } \\
\cline { 2 - 5 } & Recommended dose & Farmers' dose & Recommended dose & Farmers' dose \\
\hline ZT-DSR & $37.39^{\mathrm{e}}$ & $45.28^{\mathrm{b}}$ & $41.30^{\mathrm{d}}$ & $43.56^{\mathrm{c}}$ \\
Pu-TPR & $46.38^{\mathrm{b}}$ & $49.29^{\mathrm{a}}$ & $46.46^{\mathrm{b}}$ & $48.67^{\mathrm{a}}$ \\
\hline Sem $( \pm)$ & \multicolumn{4}{|c}{1.058} \\
LSD $(0.05)$ & \multicolumn{4}{|c}{3.171} \\
\hline
\end{tabular}

Note: ZT-DSR, Zero tilled direct seeded rice; Pu-TPR, Puddled transplanted rice; ns, non-significance. Treatments means followed by different letter (s) are significantly different among each other based on DMRT at 5\% level of significance

(A)

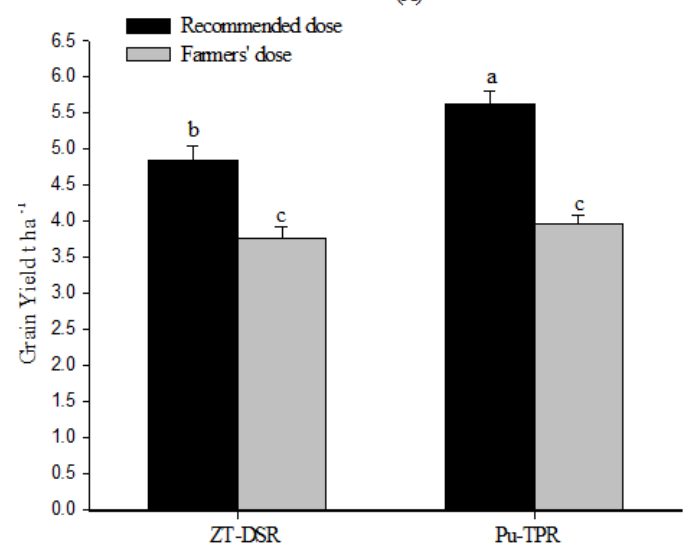

(B)

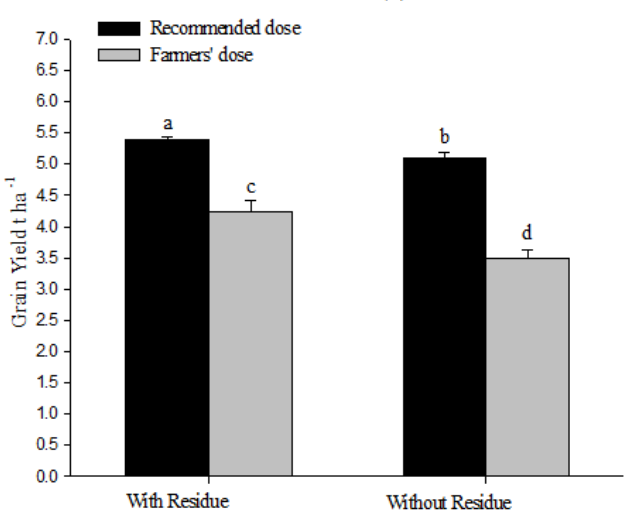

Figure 3. Grain Yield as influenced by interaction between establishment methods and nitrogen dose (A) and residue and nitrogen dose (B) in Chitwan during 2016

There was significant interaction of establishment methods and nitrogen dose on grain yield of rice (Figure 3A). In both establishment methods farmers' dose had statistically similar yield but in the recommended dose Pu-TPR had significantly higher grain yield than ZT-DSR. Similarly, there was also significant interaction of residue and nitrogen dose on grain yield of rice (Figure 3B). Residue with recommended dose had significantly higher grain yield which was followed by without residue in recommended dose and by with residue in farmers' dose and without residue in farmers' dose had statistically lower grain yield.
Three way interactions of establishment methods, residue management and nitrogen dose were recorded for harvest index (Table 5). In puddled TPR, harvest index recorded for farmers' dose was significantly higher than for the recommended dose under both residue kept and removed. But in ZT-DSR, harvest index was significantly higher for residue removed as compared to residue retained treatments under recommended nutrient dose while similar for farmers-nitrogen dose. 


\section{Conclusion}

Grain, straw and total nitrogen uptake were found higher when higher amount of residue and nitrogen were applied in the soil. In establishment methods, ZT-DSR had higher straw nitrogen uptake than Pu-TPR. Different nitrogen use efficiencies values showed that there were higher efficiencies in farmers-nitrogen dose than recommended dose practices. Establishment methods had no effect on grain yield of rice but higher the amount of residue and nitrogen applied then they had significantly higher grain and straw yield.

\section{Acknowledgments}

The authors would acknowledge National Maize Research Program (NMRP), Rampur, Chitwan for providing the research plot to conduct the research trial and Agronomy Department of Agriculture and Forestry University (AFU) and all the staffs of NMRP and AFU.

\section{References}

Adhikari BN, Joshi BP, Shrestha J, Bhatta NR. 2018. Genetic variability, heritability, genetic advance and correlation among yield and yield components of rice (Oryza sativa L.). Journal of Agriculture and Natural Resources, 1(1): 149-160.

Alam MM, Ali MH, Amin AKMR, Hasanuzzaman M. 2009. Yield attributes, yield and harvest index of three irrigated rice varieties under different levels of phosphorus. Advances in biological research, 3(3-4): 132-139.

Arshadullah M, Ali A, Hyder SI, Khan AM. 2012. Effect of wheat residue incorporation along with nitrogen starter dose on rice yield and soil health under saline sodic soil. The Journal of Animal and Plant Sciences, 22(3), 753-757. http://thejaps.org.pk/docs/v-22-3/39.pdf

Devkota S, Panthi S, Shrestha J. 2019. Response of rice to different organic and inorganic nutrient sources at Parwanipur, Bara district of Nepal. Journal of Agriculture and Natural Resources, 2(1): 53-59.

Ehsanullah II, Ahmad ASHFAQ, Randhawa SA. 2000. Effect of direct seeding and transplanting methods on the yield and quality of fine rice Basmati-370. Indian Journal of Agronomy, 38: 547-550.

Fageria NK. 2014. Nitrogen management in crop production. CRC press, 24-25.

FAO. 2017. World food situation. Food and Agriculture Organization of United Nations.

Gadal N, Shrestha J, Poudel MN, Pokharel B. 2019. A review on production status and growing environments of rice in Nepal and in the world. Archives of Agriculture and Environmental Science, 4(1): 83-87.

Gomez KA, Gomez AA. 1984. Statistical procedures for agricultural research. John Wiley \& Sons.

Gurung DB, Bhandari B, Shrestha J, Tripathi MP. 2018. Productivity of maize (Zea mays L.) as affected by varieties and sowing dates. International Journal of Applied Biology, 2(2): 13-19

Haque ME, Bell RW, Islam, MA, Rahman MA. 2016. Minimum tillage unpuddled transplanting: An alternative crop establishment strategy for rice in conservation agriculture cropping systems. Field crops research, 185: 31-39. DOI: https://doi.org/10.1016/j.fcr.2015.10.018
Hobbs PR, Singh Y, Giri GS, Lauren JG, Duxbury JM. 2002. Direct seeding and reduced tillage option in the rice-wheat systems of Indo-Gangetic Plains of South Asia. In: Pandey S, Mortimer M, Wade L, Tuong TP, Lopez K, Hardy B. (Eds.), Direct seeding: research issues and opportunities. Philippines, International Rice Research Institute, 201-218.

Karkee SS, Sah SK, Marhatta S, Dhakal S, Kandel M, Shrestha J. 2019. Nitrogen uptake and economics of black rice (Oryza sativa L. indica) under different crop geometries and nitrogen management practices. Archives of Agriculture and Environmental Science, 4(2): 171-176.

Kumar V, Ladha JK. 2011. Direct Seeding of Rice: recent developments and future research needs. Advances in Agronomy, 111: 297-413.

Mahajan G, Timsina J. 2011. Effect of nitrogen rates and weed control methods on weeds abundance and yield of directseeded rice. Archives of Agronomy and Soil Science, 57(3): 239-250.

MoAD. 2016. Statistical information on Nepalese Agriculture 2016/17. Ministry of Agriculture and Development, Agribusiness Promotion and Statistics Division, Kathmandu, Nepal.

Oo NML, Shivay YS, Kumar D. 2007. Effect of nitrogen and sulphur fertilization on yield attributes, productivity and nutrient uptake of aromatic rice (Oryza sativa). Indian Journal of Agricultural Sciences, 77(11): 772.

Patrick WH, Wyatt R. 1964. Soil nitrogen loss as a result of alternate submergence and drying. Soil Science Society of America Journal, 28, 647-653.

Reddy KR, Patrick WH, Broadbent FE. 1984. Nitrogen transformations and loss in flooded soils and sediments. Critical Reviews in Environmental Science and Technology, 13(4): 273-309.

Sah G, Shah SC, Sah SK, Thapa RB, McDonald A, Sidhu HS, Gupta RK, Sherchan DP, Tripathi BP, Davare M, Yadav R. 2014. Tillage, crop residue, and nitrogen level effects on soil properties and crop yields under rice-wheat system in the terai region of Nepal. Global journal of biology, agriculture and health science, 3(3): 139-147.

Sehgal J, Abrol IP. 1994. Soil degradation in India: status and impact. Oxford \& IBH Publishing Co. ISBN: 8120409310

Sharma AR, Mitra BN. 1992. Integrated nitrogen management in rice (Oryza sativa)-wheat (Triticum aestivum) cropping system. Indian J. Agric. Sci, 62: 70-72.

Sharma AR, Ghosh A. 2000. Effect of green manuring with Sesbania aculeata and nitrogen fertilization on the performance of direct-seeded flood-prone lowland rice. Nut. Cycl. Agroecosys., 57: 141-153. https://link.springer.com /article/10.1023/A:1009863100224

Sharma PK, Ladhaand JK, Bhushan L. 2003. Soil physical effects of puddling in rice-wheat cropping systems. In "Improving the Productivity and Sustainability of Rice-Wheat Systems: Issues and Impacts" Ladha JK, Hill JE, Duxbury JM, Gupta RK, Buresh RJ (eds.) ASA, CSSA, SSSA, Madison, WI, ASA Special Publication 65:97-113.

Shrestha J. 2019. P-Value: A true test of significance in agricultural research. Retrieved from https://www.linkedin.com/pulse/p-value-test-significanceagricultural-research-jiban-shrestha/

Singh Y. 2003. Crop residue management in rice-wheat system. In: Addressing Resource Conservation Issues in Rice-Wheat Systems of South Asia: A Resource Book, vol. (153) 153156. Rice-Wheat Consortium for the Indo-Gangetic Plains RWC CIMMYT, New Delhi, India.

Togari Y, Okamoto Y, Kumura A. 1954. Studies on the production and behavior of carbohydrates in rice plant. 1 Proc. Crop Sci. Soc. Japan, 22: 95- 97.

Zia MS, Mahmood IA, Aslam M, Yasin M, Khan MA. 2001. Nitrogen Dynamics under Aerobic and Anaerobic Soil Conditions. International journal of agriculture \& biology, 3(4), 458-460. 